\title{
An Environmental Competition Statute
}

\author{
DAVID M. DRIESEN*
}

\section{TABLE OF CONTENTS}

I. VAlue of AN EnVIRonmental Competition StATUTE .................................... 200

II. PROBLEMS WITH THE EXISTING LAW ................................................................. 201

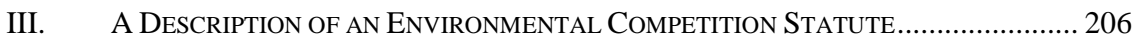

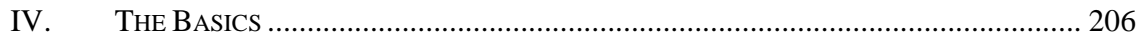

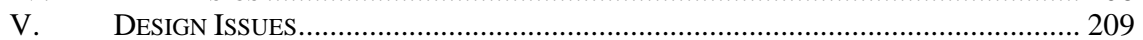

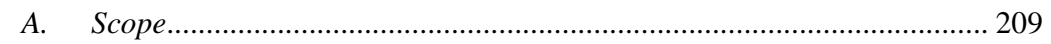

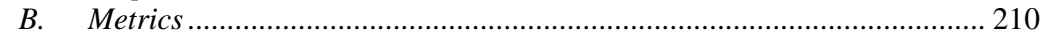

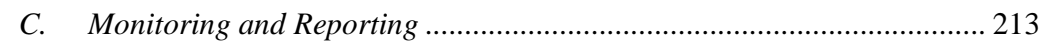

D. Definition of Competitors .................................................................... 213

E. Discouraging Collusion .......................................................................... 214

F. Minimizing Litigation ..................................................................... 214

VI. Concerns That Such A StatUte May Raise ................................................. 215

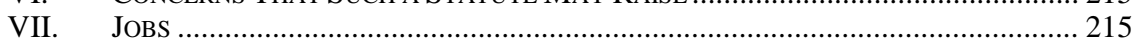

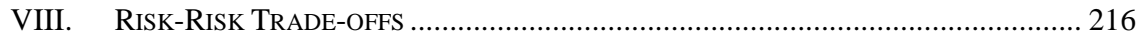

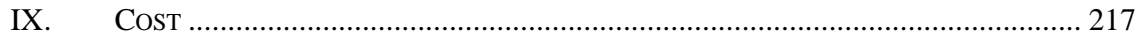

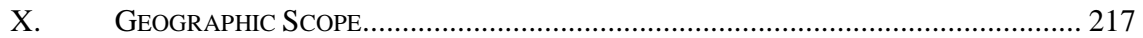

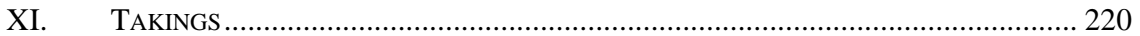

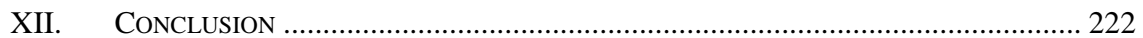

* University Professor, Syracuse University. This Article, with minor changes, originally appeared as Chapter 8 in BEYOND ENVIRONMENTAL LAW: POLICY PROPOSALS FOR A BetTER Future (Alyson C. Flournoy \& David M. Driesen, eds., 2010). I thank Cambridge University Press for its permission to publish this Article. 
The next generation of environmental law should use economic incentives to creatively stimulate innovation in environmental technology. This Article proposes an environmental competition statute as a means of stimulating movement toward a more sustainable future. Such a statute would authorize those who achieve low emissions to collect the cost of achieving low emissions plus a premium from competitors with higher emissions.

This Article briefly explains the value of using this mechanism. It then canvasses the problems with the first and second generation of environmental law that an environmental competition statute can help us overcome. A detailed description of an environmental competition statute follows. The Article then turns to possible objections to the scheme not addressed in the previous material. It closes with a brief conclusion.

\section{VALUE OF AN ENVIRONMENTAL COMPETITION STATUTE}

We have achieved a number of advances in material welfare because entrepreneurs seek to get rich by developing and introducing innovations. Examples include the cellular phone, the personal computer, and various uses of the Internet. Innovators' ability to gain market share through productive change is limited only by their imagination and ability to meet potential demand. Unfortunately, the free market rarely encourages innovations improving the environment because they usually benefit the public as a whole rather than particular consumers paying for favorable environmental changes. ${ }^{1}$

An environmental competition statute can potentially encourage contests to improve environmental quality comparable to the ongoing competition to realize other sorts of improvements. It aims to allow the capabilities of innovators free rein in improving environmental quality. It makes it possible for anybody reducing pollution to realize a profit from doing so.

The statute also creates risks for those who fail to advance and innovate, comparable to the risks faced by noninnovators in competitive markets for nonenvironmental goods and services. Just as makers of mainframe computers must adapt to the threat posed by personal computers or risk losing market share, those who fail to adopt the latest environmental technology should lose money to faster-moving competition. This statute allows environmental innovators to prosper at the expense of environmental laggards, thereby allowing environmental markets to function like other

1. See David M. Driesen, The Economic Dynamics of Environmental Law 98102 (2003) (discussing the private market's limitations in encouraging innovation protecting the environment). 
competitive markets. In short, an environmental competition statute encourages competition to improve the environment.

\section{PRoblems WITH THE EXISTING LAW}

Most existing law allows government officials' timidity to limit our environmental achievements. ${ }^{2}$ The law authorizes federal and state officials to limit the amount of pollution facilities can emit. The officials administering these laws usually must take into account the costs our most antiquated industry will face in thinking about mandating environmental change. ${ }^{3}$ They rarely, however, actively consider the economic benefits that those with newer technologies might realize from substantial positive environmental change when establishing new standards. ${ }^{4}$ As a result, even when modernization would generate new jobs and greatly improve the environment; government regulations only rarely demand significant changes in approach.

Government officials often feel obliged when setting standards for an entire industry to make sure that every company in an industry can meet the standards it sets. ${ }^{5}$ Although the law authorizes and sometimes requires regulations based on the achievements of the best performers, ${ }^{6}$ government officials tend to avoid aggressive regulation because of the political problems that tough standards would create. ${ }^{7}$ Although in the market for consumer goods competition tends to make the best performers the trendsetters, in environmental law, laggards have a big influence on the quality of environmental performance. This feeling of obligation leads to standards that do not reflect the full capabilities industry possesses to

2. See id. at 112-22 (discussing the structure and economic dynamics of government decision making in detail).

3. See, e.g., Nat'l Renderers Ass'n v. EPA, 541 F.2d 1281, 1288-89 (8th Cir. 1976) (finding a water-pollution rule arbitrary because the EPA did not adequately consider whether costs would affect the economic viability of medium-sized facilities).

4. Cf. Miguel Mendonca, Feed-in Tariffs: Accelerating the Deployment of Renewable Nuclear Energy 43 (2007) (Germany's feed-in tariff system to encourage renewable energy created job growth in the renewable energy sector).

5. See, e.g., Nat'l Lime Ass'n v. EPA, 627 F.2d 625, 632 (D.C. Cir. 1980) (reversing a performance standard because the EPA could not adequately show that its limited data adequately took into account operational variables throughout the industry).

6. See, e.g., 42 U.S.C. $\S \S 7412(\mathrm{~d})(3)$.

7. See, e.g., Nat'l Lime Ass'n v. EPA, 233 F.3d 625, 632 (D.C. Cir. 2000) (remanding because EPA ignored statutory commands to show that all sources can achieve the standards set under the most adverse conditions). 
improve environmental performance. ${ }^{8}$ Government officials often base their regulations on the technical capabilities of pollution control technology. Government officials often, however, have limited knowledge of industry capabilities to improve environmental performance. As a result, they tend to demand relatively modest improvement based on well-understood technology. This has been the case, to some degree, even under statutory provisions designed to force technology. ${ }^{9}$

The judiciary plays a role in exacerbating this problem because industry regularly litigates to challenge rules limiting its pollution. Government officials know that courts can block implementation of rules if judges find the rules unreasonable. ${ }^{10}$ Although the relevant statutes only authorize reversal of arbitrary and capricious discretionary decisions, courts sometimes give rules a very hard look. Because officials cannot predict precisely how courts will apply the rather vague standards governing judicial review of agency rules, they tend to shy away from stringent requirements unless they have very good information indicating that facilities have known techniques available for meeting them.

Many policy-makers associate this problem of government regulation failing to encourage substantial innovation with command-and-control regulation. But this timidity problem also limits the achievements of emissions trading programs. Emissions trading programs require government officials to set limits on the amount of pollution that polluting facilities emit. ${ }^{11}$ The emissions trading law then authorizes polluters subject to those limits to avoid them if they purchase equivalent extra reductions from other facilities, which makes it possible to meet bureaucratically

8. See generally Thomas O. McGarity, Some Thoughts on Deossifying the Rulemaking Process, 41 DuKE L.J. 1385 (1992).

9. David M. Driesen, Distributing the Costs of Environmental, Health, and Safety Regulation: The Feasibility Principle, Cost-Benefit Analysis, and Regulatory Reform, 32 B. C. ENVTL. AFF. L. REv. 1, 14-16 (2005) (explaining how judicial demands for a rational basis for technology-based rules have limited technology forcing). Bruce La Pierre, Technology-Forcing and Federal Environmental Protection Statutes, 62 IowA L. REV. 771, 805-31 (1977) (contending that judicial requirements that agencies identify at least one technology capable of achieving their promulgated standards limited agencies' ability to force technology); cf. Note, Forcing Technology: The Clean Air Act Experience, 88 YALE L.J. 1713, 1718-19 (1979) (claiming that state plans did force some technological improvement).

10. See generally Frank B. Cross, Shattering the Fragile Case for Judicial Review of Rulemaking, 85 VA. L. REV. 1243 (1999).

11. See Michael Grubb et al., Allowance Allocation in the European Emissions Trading Scheme: A Commentary, 5 ClimATE POL’y 127, 127 (2005) (describing the "allocation of allowances" as "the most ...important step" for "any emissions trading system”); David M. Driesen, Is Emissions Trading an Economic Incentive Program? Beyond the Economic Incentive/Command and Control Dichotomy, 55 WASH. \& LEE L. REV. 289, 324 (1998); Tex. Mun. Power Agency v. EPA, 89 F.3d 858, 861 (D.C. Cir. 1996) (describing the need for limits as a "necessary aspect" of "any" emissions trading program). 
chosen limits efficiently. Government officials develop the emission limits with the costs to old established industry of making changes very much in mind. They therefore usually make demands that do not require basic technological changes significantly improving societal welfare. For example, Title IV of the Clean Air Act includes a very well designed emissions trading program for sources of sulfur dioxide causing acid rain. This program has produced some of the reductions needed to address the ecological problems acid rain causes, but it has not encouraged substantial movements toward modern renewable energy technologies. ${ }^{12}$ Rather, it has encouraged traditional end-of-the-pipe controls (scrubbers) and some modest pollution prevention (low sulfur coal). ${ }^{13}$ The acid rain program has not made the purveyors of the most promising innovative environmental technologies rich. So, it has not functioned to produce the kind of wide-open competition that has enriched people with new ideas providing material benefits to consumers. ${ }^{14}$

The same problem of government timidity limits the efficacy of pollution taxes. Economists support pollution taxes as an efficient environmental protection instrument. If the traditional U.S. antipathy toward taxes ever abated sufficiently to allow a pollution tax law to pass at all, government officials would have to choose the tax rates to apply to pollution. They would probably find it politically difficult to set rates sufficiently high to stimulate significant innovation in environmentally friendly technologies.

Existing law does not provide a continuous incentive to innovate and go beyond compliance. ${ }^{15}$ Even in an emissions trading program, once the operators of facilities regulated by the program have met government set

12. See A. Denny Ellerman et al., Markets for Clean Air: the U.S. Acid RAIN PRogram 130 (2000).

13. See David M. Driesen, Does Emissions Trading Encourage Innovation?, 33 ENVT'L L. ReP. 10,094, 10,105 (2003); Byron Swift, Command without Control: Why Capand-Trade Should Replace Rate Standards for Regional Pollutants, 31 EnVT'L L. REP. 10,330, 10,332 (2001) (describing scrubbers and low-sulfur coal as the principal compliance techniques).

14. Cf. Margaret R. Taylor, Edward S. Rubin, \& David A. Hounshell, Regulation as the Mother of Invention: The Case of SO2 Control, 27 LAW \& POL'Y 348, 370 (2005) (finding less innovation under the acid rain program than under the commandand-control regime preceding it); David Popp, Pollution Control Innovations and the Clean Air Act of 1990, 22 J. POL'Y ANAL. \& MGMT. 641 (2003) (finding more patenting of environmental technology under command and control than under the acid rain trading program, but finding a different type of innovation under trading).

15. See Driesen, supra note, at 10,099-101 (explaining in detail why a trading program fails to provide continuous incentives for environmental improvement); Driesen, supra note 9, at 324-27 (same). 
pollution limits by purchasing credits from overcomplying plants or through local reductions, no incentive exists to go further. ${ }^{16}$ Because of this limited demand for credits, only a limited incentive exists to overcomply; rational polluters will only produce as many credits as noncomplying facilities need to achieve compliance, not more. The incentive to improve environmental performance lasts only until the compliance deadline comes up. Emissions trading provides no incentives for net reductions beyond those envisioned by government officials, who set caps with limited information about private-sector capacity for innovation.

Proponents of emissions trading often assert that government officials can remedy the lack of incentive for continuous innovation by setting new limits that apply after a compliance deadline expires. But setting new limits can be politically difficult. Industry can avoid cost by opposing fresh limits, and it frequently does so. ${ }^{17}$ Because government responses to the pressures it faces are unpredictable, government regulation, whether by emissions trading or conventional approaches, does not provide a secure climate for investment and deployment of innovative environmental technologies, even though it has secured some significant incremental improvement and occasional innovations. ${ }^{18}$

Pending climate change legislation, if enacted, may provide a more secure climate for investment than previous trading programs because of the presence of meaningful long-term targets. But such targets are unlikely to be wholly adequate to address climate change. Even in the rare case when a trading program provides a good climate for long-term investment, an

16. See Robert W. Hahn \& Robert N. Stavins, Incentive-Based Environmental Regulation: A New Era from an Old Idea, 18 EcolOGY L.Q. 1, 8-9 \& n.33 (1991) (recognizing that emissions trading tends to reach an equilibrium).

17. Accord Andrew McFee Thompson, Comment, Free Market Environmentalism and the Common Law: Confusion, Nostalgia, and Inconsistency, 45 EMORY L.J. 1329, 1359 (1996) (noting the pressures that bureaucrats face to overallocate allowances in a trading scheme); see, e.g., Inho Choi, Global Climate Change and the Use of Economic Approaches: The Ideal Design Features of Domestic Greenhouse Gas Emissions Trading and an Analysis of the European Union's CO2 Emissions Trading Directive and the Climate Stewardship Act, 45 NAT. Resources J. 865, 902-03 (2005) (describing California's RECLAIM program as a failure because caps were set too high); Axel Michaelowa \& Sonja Butzengeiger, EU Emissions Trading: Navigating Between Scylla and Charybdis, 5 CLIMATE POL'Y 1, 5 (2005) (explaining how lobbying in the European Union led to goals in the first phase of its emissions trading scheme that provided for little departure from business-as-usual levels of carbon emissions); Grubb et al., supra note 11, at 132-33 (same); Tex. Mun. Power Agency v. EPA, 89 F.3d 858, 861 (D.C. Cir. 1996) (involving a claim to additional emission allowances); Indianapolis Power \& Light Co. v. EPA, 58 F.3d 643, 647 (D.C. Cir. 1995) (same); Madison Gas \& Elec. Co. 25 F.3d 526, 526 (7th Cir. 1994) (same); Mononganhela Power Co. v. Reilly, 980 F.3d 272, 272-74 (4th Cir. 1992).

18. See Driesen, supra note 13 , at 10,103-05. 
environmental competition statute can usefully supplement and make up for weaknesses in the cap.

A tax program can provide a continuous reduction incentive but only for a limited class of innovation, those with marginal costs less than the marginal tax rate. Taxes would not provide good incentives for important, cutting-edge technologies that require significant investments, putting their marginal costs above marginal tax rates, even if such investments would lower costs and improve environmental quality in the long run.

The idea for an environmental competition statute arises from experience with second-generation economic incentives. These incentives fall into two categories - negative incentives that penalize pollution, such as pollution taxes, and positive incentives that reward pollution reductions, such as subsidies. Environmental law, however, functions most dynamically when negative economic incentives fund positive economic incentives. Governments occasionally enacted or considered such programs during the second generation of environmental law. Thus, New Zealand, for example, imposed licensing fees on fishing, a negative economic incentive, and used the revenue from these fees to pay fishermen to retire, a positive economic incentive. ${ }^{19}$ France taxed water pollution and used some of the revenue to fund wastewater treatment. The Regional Greenhouse Gas Initiative, an emissions trading program limiting greenhouse gas emissions from electric utilities in the northeastern United States, features auctioning of emission allowances, and states may use these revenues to fund energy-efficiency improvements. ${ }^{20}$ The California legislature considered a program, Drive + , that would impose fees on consumers purchasing energy-inefficient vehicles and give those fees to consumers purchasing energy-efficient vehicles as a rebate. ${ }^{21}$ And finally, New Hampshire officials considered an Industry Average Performance System, which would redistribute pollution taxes to low-polluting companies. An environmental competition statute seeks to build on these cutting-edge, second-generation reforms to stimulate increased innovation.

19. See Tom Tietenberg, Using Economic Incentives to Maintain our Environment, 33 Challenge 42, 43 (1990).

20. See David M. Driesen, The Changing Climate for United States Law, 1 Climate Change L. Rev. 33, 38 (2007) (discussing movement toward auctioning under the Regional Greenhouse Gas Initiative).

21. Nathaniel Greene \& Venessa Ward, Getting the Sticker Price Right: Incentives for Cleaner, More Efficient Vehicles, 12 PACE ENVT'L L. REV. 289, 346 (1998). 
Increased innovation is important, because innovation increases our capacity to address environmental problems over time and can reduce the cost of doing so. Yet economists recognize that markets generally stimulate insufficient innovation. The reason for this is that developers of innovation cannot capture all of the benefits that innovation creates for society. These positive spillovers (benefits that do not generate rents for the innovator) arise because innovations can contribute knowledge that spurs additional innovation by competitors. ${ }^{22}$ These observations about markets' limits in spurring innovation apply to the markets in pollution control technology that first-generation performance standards create and to the markets that second-generation emissions trading programs create. The value of innovation and the limits of markets in encouraging it suggest the need for creative measures to stimulate innovation, such as an Environmental Competition Statute.

\section{A DESCRIPTION OF AN ENVIRONMENTAL COMPETITION STATUTE}

This section begins with a description of the statute's basic features and the rationale for them. It then discusses a host of design issues that a legislature creating such a statute would face. In general, these issues are similar to issues that policy makers confront in designing other marketbased and traditional regulatory programs.

\section{THE BASICS}

An environmental competition statute would aim to stimulate a race to the top-a competition to develop and deploy environmentally superior technology. To stimulate this race, an environmental competition statute authorizes those producing products or services with low emissions to collect fees from competitors with higher emissions. These fees should be sufficient to fund the full cost of using and developing an environmentally superior approach and should provide a premium beyond that amount.

Thus, the law would have two components. First, it would set out a requirement that a relatively high polluter pay any low-polluting competitor requesting a fee. The fee should be a dollar amount equal to the amount

22. See Gregory N. Mandel, Promoting Environmental Innovation and Intellectual Property Innovation: A New Basis for Patent Rewards, 24 TEMPLE J. ENVTL. L. \& TECH. 51, 56 (2006) (if a person "builds a better mousetrap," others may copy it); RICHARD A. POSNER, CATASTROPHE: RiSK AND RESPONSE 123-24 (2004) (third parties' ability to use information makes it difficult for inventors to keep all the value their inventions create). See generally Brett Frischman \& Mark A. Lemley, Spillovers, 107 ColuM. L. REv. 257 (2007). 
the low-polluting competitor spent to achieve lower emissions than the higher polluter. The low polluter could demand this fee from any higherpolluting competitor it chooses. Second, the legislation would set out a premium that the high polluter must pay beyond the low polluter's cost. For example, the law could require that, on demand, any polluter with higher emissions than the competing company making the demand must pay the low polluter the cost it incurred to achieve low emissions plus 10 percent of its abatement costs.

This approach would allow environmental markets to emulate the economic dynamics of highly competitive markets. In such markets, firms innovate to take market share from other firms. When they innovate successfully, they in effect take money from their competitors, as their revenues increase and their competitors' revenues diminish. The environmental competition statute's transfer payment provision creates this same effect for environmental goods.

Absent such a statute, environmental markets do not produce freewheeling competition for market share to fully meet consumer demand for environmental goods. Consumers want environmental benefits, but because these benefits are public goods, consumers cannot purchase them in free markets. Thus, I may want clean air, but I cannot pay anybody to produce it. No one party can provide me with clean air, because dirty air comes about as a result of the actions of multiple actors, all or most of whom must clean up to produce clean air. This public character of environmental goods (and bads) distinguishes them from private goods, like air conditioners, that one can purchase from a single party.

Government regulation serves to stimulate provision of the public good of environmental quality. But it does so through a less dynamic mechanism than competition to seize market share. It creates a demand for a discrete government-mandated environmental improvement, which can, as we have seen, be inadequate and take insufficient advantage of private-sector capacity to produce environmental improvements.

The kind of economic dynamic an environmental competition statute provides is powerful. It uses fear and greed to motivate innovation, combining an opportunity for profit for innovators with a risk of loss for those who fail to innovate as quickly as their competitors. By doing this, it allows environmental law to emulate the most widely admired feature of free markets, their tendency to stimulate technological advances bettering our lives. Free markets in private goods likewise depend on fear and greed to motivate technological advancements. Opportunities 
for profit and fear of loss stimulate the risk taking that must occur to create significant technological advances.

Absent such a statute, each polluter often must internalize (pay for) the cost of pollution control itself. But it may externalize (pass on to others) the costs of pollution-a degraded environment and serious public health problems. This asymmetry discourages cleanup. An environmental competition statute allows polluters to systematically externalize the costs of pollution control, just as polluters can now externalize pollutions' costs. This cost externalization frees them to employ all their ingenuity to cleanup.

Sound principles support the idea of an environmental competition statute. In confronting environmental problems, we should "do the best we can." 23 Too often, however, we settle for mediocre environmental standards - standards that demand some improvement but not nearly as much as the market is capable of delivering. This statute tends to foster technological progress by letting the cutting-edge innovators set the pace. Just as in a market for consumer goods and services, a firm must keep up with what the best firms are doing or lose money, this statute likewise requires firms to match the achievements of their best environmental competitors or risk financial consequences. This statute allows firms to profit from environmental leadership and encourages them to truly do the best they can in advancing environmental quality.

An environmental competition statute also helps overcome problems inherent in the economic dynamics of regulation. Frequently, firms resist regulation en masse, and all regulated firms share an interest in defeating enforcement. Because we all finance firms' antienvironmental litigation and lobbying when we purchase the goods they make, they have a lot of money to use in thwarting progress. The environmental competition statute should make about half of the polluting firms into enforcers of the statute. It promises distinct economic benefits to the cleanest firms, which may lead some firms to support such a statute. In these ways, the environmental competition statute seeks to overcome the economic dynamics at the heart of regulatory failure to keep pace with environmentally destructive activities. ${ }^{24}$

23. See A New Progressive Agenda for Public Health and the Environment: A Project of the CENTER FOR Progressive Regulation 57-70 (Christopher H. Schroeder \& Rena Steinzor eds., 2004) (discussing this concept as a principal to guide environmental law).

24. See Driesen, supra note 1, at 113-35 (analyzing the dynamics of this failure in detail). Cf. DAvid GoldSTEIn, SAVING ENERgy Growing JobS: How ENVIRONMENTAL Protection Promotes Economic Growth, Profitability, InNOVATION, AND COMPETITION 172-76 (2007) (explaining how trade associations repress competition to profit from environmental protection and pressure the government to adopt weak standards or none at all). 


\section{DESIGN IsSUES}

\section{A. Scope}

The legislature may make the obligation to pay low-polluting competitors a general requirement for all classes of pollutants and industries, or may instead focus on a particular industry and set of pollutants of concern. Congress (or a state legislature) could, for example, enact an environmental competition statute to focus on all emitters of carbon dioxide, the most important greenhouse gas causing global warming. The owner of a new solar plant, for example, could collect all of the costs of plant construction from owners of existing power plants with higher emissions plus a premium - a dollar amount written into the legislation to provide a profit margin for each low emitter. Similarly, makers of vehicles with low carbon dioxide emissions could demand that the makers of vehicles with higher emissions pay the additional costs associated with making their vehicles lower emitting.

Design questions will arise about how to define the class of polluters with responsibilities and opportunities under the environmental competition statute, just as they do under traditional regulation and in market-based programs. Thus, for example, a program that focuses only on emissions characteristics built into cars will not allow consumers, who may influence emissions through their driving behavior, to play in this market. Such a choice may be justifiable in all of these contexts because of the difficulty of monitoring and regulating individual driving behavior. But it means that we should bear in mind that none of these approaches is a panacea that works for all facets of all programs. We should, however, in defining polluters for purposes of environmental competition, try to capture as much of the pollution generated throughout the life cycle as is feasible.

For simplicity's sake, it may be wise to authorize those who clean up to collect fees from any polluter that they choose to target, but require that they choose only a single polluter. The cleaner company will likely choose high-polluting and well-capitalized targets, as it will be easy to prove that they are cleaner than a very dirty company, and it will be easiest to collect from a wealthy company. One could use variation in the premium paid to cleaner companies to encourage collection from the dirtiest companies, but this would either require complicated legislative line drawing or very difficult data collection by the polluter trying to recover its costs. 
Congress (or a state legislature) could enact the environmental competition statute without amending any existing law. It would be a means of supplementing basic obligations with incentives to go beyond those obligations, or of encouraging new efforts where little has been done (e.g., global warming).

The legislation, however, would function best if it addressed some matters of detail. The legislation might define the pollutants and/or industries it applies to. It would be important to define the industry in terms of broad functions (e.g., the personal vehicle transportation industry), not specific market niches (e.g., sport-utility-vehicle makers). The whole point is to force transfer payments between companies on the basis of environmental performance in meeting basic consumer needs. This requires identification of the bounds of an industry, as only competitors must pay a low-polluting firm under this approach. Because consumers buying cars have a choice between sedans and sport-utility vehicles, for example, defining a category to include all forms of personal transportation makes sense.

This legislation will be most helpful in areas where we anticipate the need for very significant technological change. Climate change is such an area. Scientists suggest that we will need more than a 50 percent cut in global emissions below 1990 levels by 2050 to avoid dangerous climate change. ${ }^{25}$ Because developing countries' emissions are expected to rise during most of this period, this may require cuts of 80 percent or more in developed countries' emissions. Because carbon dioxide emissions constitute about 80 percent of the gases on the basis of warming potential, this implies a massive move away from fossil fuels. Such a move will require-major technological changes. Other areas may also benefit from such an approach.

\section{B. Metrics}

The environmental competition statute will have to provide some guidance about how to compare the emissions of competing firms. The measurement issue is not fundamentally different from issues in traditional regulation, where we also must figure out how to measure emissions and fairly take into account differences among firms. But in the context of

25. See James E. Hansen, A Slippery Slope: How Much Global Warming Constitutes "Dangerous" Anthropogenic Interference, 68 Climate CHANGE 269, 277 (2005) (stating that a two-degree Celsius temperature rise "almost surely takes us well into the realm of dangerous" climate change); Malte Meinshausen, What Does a $2 \mathrm{C}$ Target Mean for Greenhouse Gas Concentrations? A Brief Analysis Based on Multi-Gas Emission Pathways and Several Climate Sensitivity Uncertainty Estimates, in Avoiding Dangerous Climate Change 269-70 (Hans Joachim Schellnhuber et al. eds., 2006) (estimating that limiting temperature rise to less than two degrees Celsius likely requires a 55 percent reduction below 1990 emission levels by 2050). 
environmental competition, we may profitably treat some of the issues a little differently than we have in other contexts.

An important aspect of the measurement problem involves the choice of a metric on which to base comparisons. A mass-based metric will not work terribly well in this context. Suppose, for example, that one power plant generates one hundred tons of carbon dioxide per year and another generates two hundred tons of carbon dioxide per year. One might think that it would be appropriate to consider the two-hundred-ton facility as the facility with higher emissions, and allow the hundred-ton facility to collect fees from the two-hundred-ton facility. This might, however, be inappropriate. Suppose that the two-hundred-ton facility provides electricity to a million people and the hundred-ton facility provides electricity to just one thousand people. It does not seem fair, in such a situation, to consider the larger facility the higher emitter just because it is big and supplies a lot of customers. A better metric would be tons of carbon dioxide per kilowatt hour per year. This would normalize emissions by the amount of pollution per unit of output. In general, this should be the approach. We should measure and compare emissions by the mass of emissions generated annually per unit of output.

This sort of issue arises outside of the environmental competition statute as well. For example, in designing principles for allocating reduction obligations to electric utilities as part of the proposed U.S. cap-and-trade program addressing climate disruption, legislators rejected an allocation formula based on the amount of electricity generated, recognizing that such an approach penalizes utilities that have low per capita emissions because they have funded energy efficiency. Accordingly, some of the bills included energy-efficiency-based adjustments to the electricity-output allocation formula. The per-customer approach seeks to accomplish the same thing in a simpler way.

We could define the unit of output differently, in terms of numbers of customers served in various categories (e.g., residential and industrial). This would prove more complicated to administer fairly but would provide incentives to pay for energy-efficiency improvements, as these would reduce the amount of emissions per customer. These sorts of issues, what metric to choose, are not unique to the environmental competition statute; they also influence the incentives provided by trading programs and traditional regulation. But in all contexts, wise choices of metrics can make incentives more or less powerful and design more or less 
complicated, as they do when regulators design other market-based programs or traditional performance standards.

Another threshold issue involves deciding whether to focus on emission levels or emission reductions. This issue, too, has its counterparts in existing regulatory programs. Regulators setting a traditional first-generation performance standard can focus on future emission reductions by demanding even percentage reductions from firms, meaning that clean firms must clean up just as much as dirty firms (in percentage terms) to escape liability. Alternatively, they can set absolute uniform emission limits, which require significant reductions in firms with high baseline emissions but much fewer reductions (or none at all) from relatively clean plants. ${ }^{26}$ The environmental competition statute likewise could use emission levels as the trigger for liability, authorizing low emitters to collect payments from high emitters. Alternatively, the statute could employ an emissions reduction approach, basing payments on relative amounts of emission reductions after the program was enacted. For reasons that appear below, a properly designed emissions-level approach functions much better than the emission reduction approach.

The emissions-level approach maximizes pressure on dirty plants to clean up. It makes them immediately vulnerable to demands for payment, even without their cleaner competitors undertaking any new projects, because dirty plants will, at the outset, have more emissions than clean ones. If this approach is used, the statute should give plants a few years before any demands for payment can be made to give owners of relatively dirty plants a chance to clean up to escape fee-payment obligations.

An emission reduction approach works less well because it may grandfather in existing emissions. Under this approach, a very dirty coalfired power plant could reduce emissions and claim a penalty from a natural gas power plant that produced fewer emission reductions, even if the gas-fired power plant has lower emission levels (as gas is inherently cleaner than coal). It minimizes economic dynamic pressure for fundamental technological changes (e.g., fuel choices) and maximizes fairness to existing polluters. It fails to force significant change because it accepts the status quo baseline as a given. Worse, in some contexts, it can reward dirty facilities at the expense of clean competition. For example, under this approach, an existing coal-fired power plant could reduce its emissions slightly and then collect the cost of doing that from a zero-emission solar facility, which cannot reduce its emissions (as it is impossible to go below zero emissions). Where such perverse outcomes are likely, the

26. See Driesen, supra note 1, at 193-95 (discussing the differences between percentage reduction and fixed-level standards). 
emission reduction approach should not be used. By contrast, an emissionslevel approach maximizes pressures for environmental advances.

\section{Monitoring and Reporting}

As with emissions trading, pollution taxes, and performance standards, an environmental competition statute relies on accurate monitoring and reporting of pollution levels. The environmental competition statute, like other economic-incentive-based approaches, will work best in contexts in which reliable monitoring or estimation is feasible. Provisions in the statute should require the use of the best monitoring techniques available. In addition, polluters must report their pollution, not just to the government, but also to their competitors. This reporting will make it possible for competitors to compare emissions for the sake of planning environmental improvements to avoid fees, and for the sake of deciding who to seek fees from after a low pollution level is achieved. The reporting should take the form of regular postings on an Internet page accessible to all. Because the statute should be based on comparisons of pollution per unit of output level, the reporting should cover both emissions and production numbers.

\section{Definition of Competitors}

The environmental competition statute needs to define competitive markets for the sake of establishing who may collect fees from whom. Existing environmental law generally regulates polluters in an industry category, often defined by standard industrial classification (SIC) codes. SIC codes, however, do not comprehensively identify all ideally relevant competitors in a system designed to reward environmentally friendly innovation and apply negative economic incentives to dirtier means of meeting the same consumer goal. In some cases, SIC codes will be too narrow and in some cases too broad. Ideally, someone who develops, for example, a system of integrated pest management (IPM) that makes it possible to increase crop yields with little or no pesticide use should be able to collect a payment from pesticide manufacturers that compete with him or her to increase crop yields. Even if the IPM developers operate a research farm and the pesticide manufacturer operates a pesticide plant, the statute should regard them as competitors (or allow courts to develop a common law of competition based on broad principles).

The application of the statute to a well-defined group of polluters and pollutants with very clear specific definitions of competitors would 
minimize disputes about who is a competitor. But broader definitions of competitors would produce much more innovation and fundamental change in how we deliver goods and services to consumers.

\section{E. Discouraging Collusion}

The legislation should forbid communication among competitors about how firms plan to respond to the environmental competition statute. Otherwise, legislators might agree to do nothing, thereby eliminating the incentives to compete. Violation of the provisions should carry very heavy penalties, including jail terms for individuals who commit deliberate violations. Such communication should be regarded as proof of a conspiracy to prevent environmental competition in violation of antitrust principles. Absent such conspiracies, some companies with advanced environmental capabilities will likely seize the opportunity to extract payments from competitors, thereby starting the race to the top. Firms who do not view themselves as environmentally advanced may start beefing up their emission-reducing activities out of fear of becoming a target.

\section{F. Minimizing Litigation}

The legislation should also seek to minimize litigation by providing a dispute settlement mechanism, perhaps through mandatory arbitration. Disputes may arise as to who is a competitor and who has the lowest emissions. Those using continuous monitoring should be presumed to have lower emissions than competitors, unless the competitor can prove otherwise. This will encourage reliable monitoring. Still, legitimate disputes about how to estimate or measure emissions may arise. So, it is desirable to see to it that these quarrels do not become so time consuming as to blunt the program's effects. On the other hand, actions to reduce pollution to get transfer payments or to avoid having to become a payer of one can prove productive even if final settlement is delayed.

The environmental competition statute will not generate complicated environmentally fruitless disputes. The Comprehensive Environmental Response, Compensation, and Liability Act of 1980, otherwise known as Superfund, has a reputation for generating vexing disputes. This U.S. federal law makes a variety of parties associated with a toxic waste site responsible for that site's cleanup. This has often led to protracted disputes about how to apportion liability among potentially responsible parties. 
Superfund, however, has been a notable success in encouraging parties not to create new toxic waste dumps since its enactment in $1980 .{ }^{27}$ The environmental competition statute would likely stimulate a comparable scramble to avoid liability. The principle causes of protracted disputes and high transaction costs under Superfund would not exist under the environmental competition statute. Allocating responsibility under Superfund has proved difficult because obtaining good information about the past history of toxic waste dumps (e.g., who dumped, who allowed dumping) has proved difficult and the program creates great uncertainty about the eventual cleanup's scope. By contrast, the environmental competition statute will apply to facilities where the responsibility for pollution clearly belongs with the owner of the facility. It usually will not prove difficult to determine pollution levels, because pollution is ongoing, not past, and liability will arise only after cleanup is completed and documented and the costs completely known. Furthermore, one can structure the environmental competition statute to limit the parties involved to as few as two-one defendant and one plaintiff, thus avoiding the multiparty litigation that has bedeviled the Superfund program.

\section{Concerns That Such a Statute May Raise}

Competition offers great prospects for gains and advancements. But it also involves change. And change can excite fear. This section addresses some of the concerns that the environmental competition statute may bring to the forefront.

\section{JOBS}

Although an environmental competition statute may increase jobs in companies employing new low-emission approaches, it can conceivably cause job losses and even bankruptcy in high-pollution companies. In other areas of life, we accept occasional job losses as the price to pay for improvement.

Hence, nobody argued that we should throttle the personal computer to stave off job losses in the typewriter industry. If we accept these sorts

27. See Klaus Lindegaard, Environmental Law, Environmental Globalization, and Sustainable Techno-Economic Evolution, in ENVIRONMENT, TECHNOLOGY, AND ECONOMIC GROWTH 141 (Andrew Tylecote \& Jan van Der Straaten eds., 1998) (reporting a 51.8 percent reduction in waste generation between 1981 and 1985). 
of consequences as the price of progress in delivering better consumer goods or services, we should accept them, when necessary, as a sometimesnecessary cost of environmental progress.

Congress (or a state legislature) could, however, seek to protect workers from some of competition's potential consequences, just as Congress has protected workers from the consequences of other market-based environmental measures. When Congress enacted the acid-rain trading program, it recognized that the flexibility the program offered electric utilities would probably lead to more use of low-sulfur coal. Although this was good for miners in regions producing low-sulfur coal, it was not good for miners in regions producing high-sulfur coal. Decreased demand for high-sulfur coal could lead to job losses in the regions producing it. Accordingly, Congress provided transitional assistance to high-sulfur coal miners when it passed the acid rain program.

If Congress wishes to protect workers from the consequences of competition, however, the legislation providing this protection should reach all form of competition, not just environmental competition. If we wish to have a more humane policy with respect to the disruptions a competitive economy gives rise to in people's lives, it should be a broad form of protection that helps workers hurt by all sorts of market change, not just change produced by environmental laws creating competitive market dynamics.

\section{RISK-RISK TRADE-OFFS}

When an environmental competition statute targets one form of pollution, those reducing or eliminating the target pollutant may respond with measures that create different risks from those which the statute targeted. This problem is not unique to environmental competition statutes; it arises under first-and second-generation programs as well. Still, regulators should anticipate problems that might arise under such a statute. For example, if they do not wish to encourage payments from coal-fired power plant operators to nuclear power plants, because of the risks involved in nuclear power, they should draft provisions prohibiting that. Unanticipated problems, however, can arise in any program that affords industry technological choices. ${ }^{28}$

28. See David M. Driesen \& Amy Sinden, The Missing Instrument: Dirty Input Limits, 22 HARV. ENVTL. L. REV. 65 (2009). 


\section{COsT}

The environmental competition statute prototype I have outlined lacks a clear cost constraint. Under the pure form of this approach sketched earlier, clean producers can collect the cost of their cleanliness from dirty competitors no matter how costly the clean approach happened to be. A lack of cost constraint may be useful when addressing extremely serious problems that require substantial innovation, like global warming.

In practice, however, such a statute would not produce entirely unconstrained costs. ${ }^{29}$ Producers seeking to introduce cleaner processes must make sure that those processes are not so expensive to operate as to bankrupt them. If they go bankrupt, they are not a competitor that can claim compensation for cleanup. They also must spend money before they collect it and some risk exists that their competition may cleanup as well, so there remains some risk in spending too much without realizing sufficient improvements to collect from a competitor with some financial capability to make the required payments. Even though these economic constraints will apply in practice, the statute will still leave opportunities for those confident that they can beat their competitors' environmental performance without insane expenditures.

Additional cost constraints would limit the statute's effectiveness but still leave scope for significant improvements. The best way to provide an additional cost constraint is to make after the fact adjustments if costs prove excessive. An ex post approach to cost adjustment would make the program respond to actual costs rather than cost projections, which often prove inaccurate. This constitutes a substantial advantage. The adjustments could include suspending the program, putting a price cap on transfer payments, or limiting the premium paid above the cost of pollution control. All of these measures, however, would compromise the program's environmental effectiveness.

\section{GEOGRAPHIC SCOPE}

A jurisdiction enacting an environmental competition statute must also decide how to address emissions generated by activities outside the jurisdiction enacting the law. This concern arises because most markets feature competition across geographic boundaries. These issues are complicated enough that identifying an industry with substantial competition solely

29. See Driesen, supra note 1 , at 158. 
within a jurisdiction as a target for early experiments with the environmental competition statute concept commends itself as a strategy. Under this approach, only facilities in the regulating jurisdiction could collect fees, and only facilities with that jurisdiction would have to pay. We will see, however, that it is possible to handle interjurisdictional competition more robustly.

Before describing the interjurisdictional issues and ways to address them, it is worth noting that traditional environmental law, including emissions trading, faces similar issues. ${ }^{30}$ Thus, for example, when the EPA required the reformulation of gasoline to reduce air emissions from cars, effectiveness required that refiners outside the United States also reformulate their gasoline. ${ }^{31}$ Otherwise, gasoline from foreign refiners sold in the United States would undermine the program's effectiveness. Accordingly, the United States required foreign refiners to comply. ${ }^{32}$ Similarly, traditional regulation has to address transboundary impacts of production facilities' direct pollution, and it usually has done so by some process of agreements among jurisdictions. Yet we shall see that these old issues take a slightly different shape in the context of an environmental competition statute.

It seems clear that a government has jurisdiction to demand that polluters within its territory pay polluters with lower emissions, as required by an environmental competition statute. This jurisdiction would suffice to justify demanding that polluters within the jurisdiction enacting an environmental competition statute pay polluters outside the jurisdiction with lower emissions as well as polluters within it. But the question of whether a jurisdiction can demand payments from polluters outside its jurisdiction to polluters within the jurisdiction may prove more complex. For example, assume that a petroleum refinery in California produces carbon dioxide emissions. It competes with refineries in Texas to sell oil on the interstate market. California might want to force its polluters to compete to reduce refinery carbon dioxide emissions. This would require that California law allow Texas refiners to collect fees from California refiners with lower emissions, which is not jurisdictionally problematic, as the collection would be against a California facility under California

30. See, e.g., Ozone Depleting Chloroflurocarbons, Proposed Production Restriction, 45 Fed. Reg. 66,727, 66,732-33 (1980) (discussing options for addressing imports of ozone-depleting chemicals under a proposed trading scheme to reduce their domestic production).

31. See George E. Warren Corp. v. EPA, 159 F.3d 616, 618-19 (D.C. Cir. 1998) (explaining that antidumping provisions of the Clean Air Act required that both foreign and domestic refiners comply).

32. See id. (describing and resolving controversy over compliance methodologies for foreign refineries). 
law. But it is not as clear that California would have regulatory jurisdiction to demand that Texas refiners pay California refiners with lower emissions. The same question could arise on the national level. For example, could the United States demand that Venezuelan refiners pay U.S. refiners with lower emissions under a U.S. environmental competition statute?

As a general matter, states can tax foreign polluters for activities in the state. Thus, California, for example, would have jurisdiction to force a Michigan car company that sells automobiles in California to pay another car company that also sells cars in California for pollution from the cars driven or sold in California. ${ }^{33}$ It is possible that California could also regulate a company that contributed emissions that affected California. ${ }^{34}$ But this category might include any company in the world that emitted carbon dioxide, so courts might be tempted to limit the reach of such an exercise of regulatory jurisdiction. In the climate-change context, emissions everywhere affect any state's welfare. Outside of that context, a state might face difficulty regulating facilities outside of its jurisdiction that compete with facilities in the jurisdiction but emit nothing that affects the regulating states. ${ }^{35}$ Either a state or the federal government would have to consider limiting a program to embrace less than the entire market that its companies compete in under an environmental competition statute. Even with such limitations in place, such programs would spur a great deal of innovation. And Congress possesses the authority to remove impediments to state environmental competition statutes arising from the Dormant Commerce Clause, the source of most of the potential restraints just mentioned. ${ }^{36}$

Furthermore, states could reach informal agreements or create interstate compacts with congressional approval to broaden the reach of their

33. The problems underlying this discussion would arise if the Supreme Court applied its Dormant Commerce Clause jurisprudence to an Environmental Competition Statute. Because this statute would not tax-it does not raise revenue for the state-it is not entirely clear that the principles of Dormant Commerce Clause tax jurisprudence would apply to it.

34. See Nat'l Geographic Soc'y v. Cal. Bd. of Equalization, 430 U.S. 561 (1997) (requiring only some "minimum connection" between the state and the taxed entity); Walter Hellerstein, Deconstructing the Debate over State Taxation of Electronic Commerce, 13 HARV. J.L. \& TECH. 549, 552 (2000) (discussing the consensus among tax scholars that states should be able to tax companies having no physical presence in the taxing state).

35. See Quill Corp. v. North Dakota, 504 U.S. 298 (1992) (holding that states cannot impose a sales or use tax on a company lacking a physical presence in a state).

36. See id. at 318. 
programs. And nations could broaden the reach of their programs through treaties.

Both states and federal governments would have to conform their programs to relevant law encouraging free trade. Nation-states must conform to World Trade Organization (WTO) agreements, such as the General Agreement on Tariffs and Trade (GATT) and the General Agreement on Trade and Services (GATS), and regional trade agreements. Similarly, U.S. states must conform to the U.S. Supreme Court's Dormant Commerce Clause jurisprudence, which infers limits on state regulation and taxation from congressional authority to regulate interstate commerce. Under all of these free-trade legal regimes, polities usually may not discriminate against companies outside their jurisdiction. ${ }^{37}$ This means that governments must resist the temptation to make an environmental competition statute a one-way street, absent a very strong justification. ${ }^{38}$ If states demand that out-of-state companies with high emissions pay instate companies with low emissions, they must also demand that in-state companies with high emissions pay out-of-state companies with low emissions. Programs that reach out-of-state polluters must be carefully crafted to avoid adverse rulings under free-trade law and to conform to limits on state regulatory jurisdiction.

\section{TAKINGS}

Many countries prohibit the government from taking private property without just compensation. In most places, this poses no problem for an environmental competition statute because the approach does not involve a government taking of private property. The U.S. Supreme Court, however, has created a unique body of law based on the idea that if government regulation goes "too far," it constitutes a taking, thus triggering a government compensation duty. Companies would probably challenge this law as a taking, both in the United States and possibly in Canada and Mexico, under the North American Free Trade Agreement (NAFTA). But this challenge should fail. The Supreme Court has held that laws requiring monetary transfers without requiring transfer of particular property do not implicate the takings clause. ${ }^{39}$ The NAFTA tribunals are extremely unpredictable, but they should not go beyond U.S. law on this, as Canada

37. See Healy v. Beer Inst., 491 U.S. 324, 336-37 (1989) (applying strict scrutiny to discriminatory measures).

38. See New Energy Co. v. Limbach, 486 U.S. 269 (1987) (invalidating an Ohio tax credit given only to local ethanol producers despite a claim that the credit helped protect the environment).

39. See E. Enters. v. Apfel, 524 U.S. 498, 539-47, 554-58 (1998) (concurring and dissenting opinions). 
and Mexico have no regulatory takings doctrine and there is no firm support for such a doctrine in the text of the NAFTA agreement.

A challenge on substantive due-process grounds should also fail (a possibility in the United States, at least). The U.S. Supreme Court upholds all laws having a mere rational basis under this doctrine. Seeking to advance environmental protection through competition may be controversial, but it certainly meets the minimal standards for rationality that govern substantive due-process cases. ${ }^{40}$

Although the Court has upheld laws transferring funds from companies to other private parties, it has struck down an especially unfair retroactive application of one such law. ${ }^{41}$ Given the changing composition of the Court and the concern the Court has expressed about retroactive legislation, designers of environmental competition statutes might wish to limit the creation of retroactive liability that might appear unfair to the Court. A simple way to do this is to allow three years after the law goes into effect before any liability can apply, which sound design demands anyway. This gives those potentially subject to liability an opportunity to reduce their emissions and thus their liability, and it avoids retroactive liability. After all, the law's purpose is to stimulate emission reductions, not payments. The prospect of payments serves only as a means toward the end of stimulating competition to clean up.

40. See generally Collins v. City of Marker Heights, 503 U.S. 115, 125 (1992) (unanimous opinion) (discussing Court's reluctance to expand the substantive-due-process doctrine).

41. Compare Pension Benefit Guar. Corp. v. Connolly, 475 U.S. 211 (1986) (upholding requirement that private companies fund retirees' pensions after terminating a retirement plan); Usery v. Elkhorn Mining Co., 428 U.S. 1 (1976) (upholding requirement that mining companies compensate former employees with black lung disease) with Eastern Enterprises, 524 U.S. 498 (striking down retroactive liability for black lung disease for a company that never promised health protection from black lung disease). 


\section{CONCLUSION}

An environmental competition statute can unleash private-sector capacity to improve the environment with little reliance on frequently lethargic government processes. In this sense, it emulates free market dynamics more faithfully than emissions trading, the signature reform of second-generation environmental law. It allows firms exercising environmental leadership to prosper, thereby discouraging laggards from resisting change. It can help usher in a more successful third generation of environmental law. 